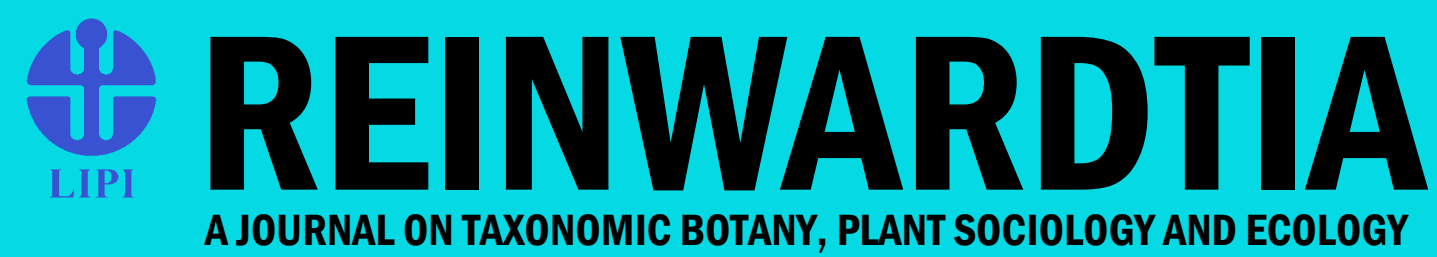

ISSN 0034 - 365 X | E-ISSN 2337 - 8824 | Accredited 792/AU3/P2MI-LIPI/04/2016
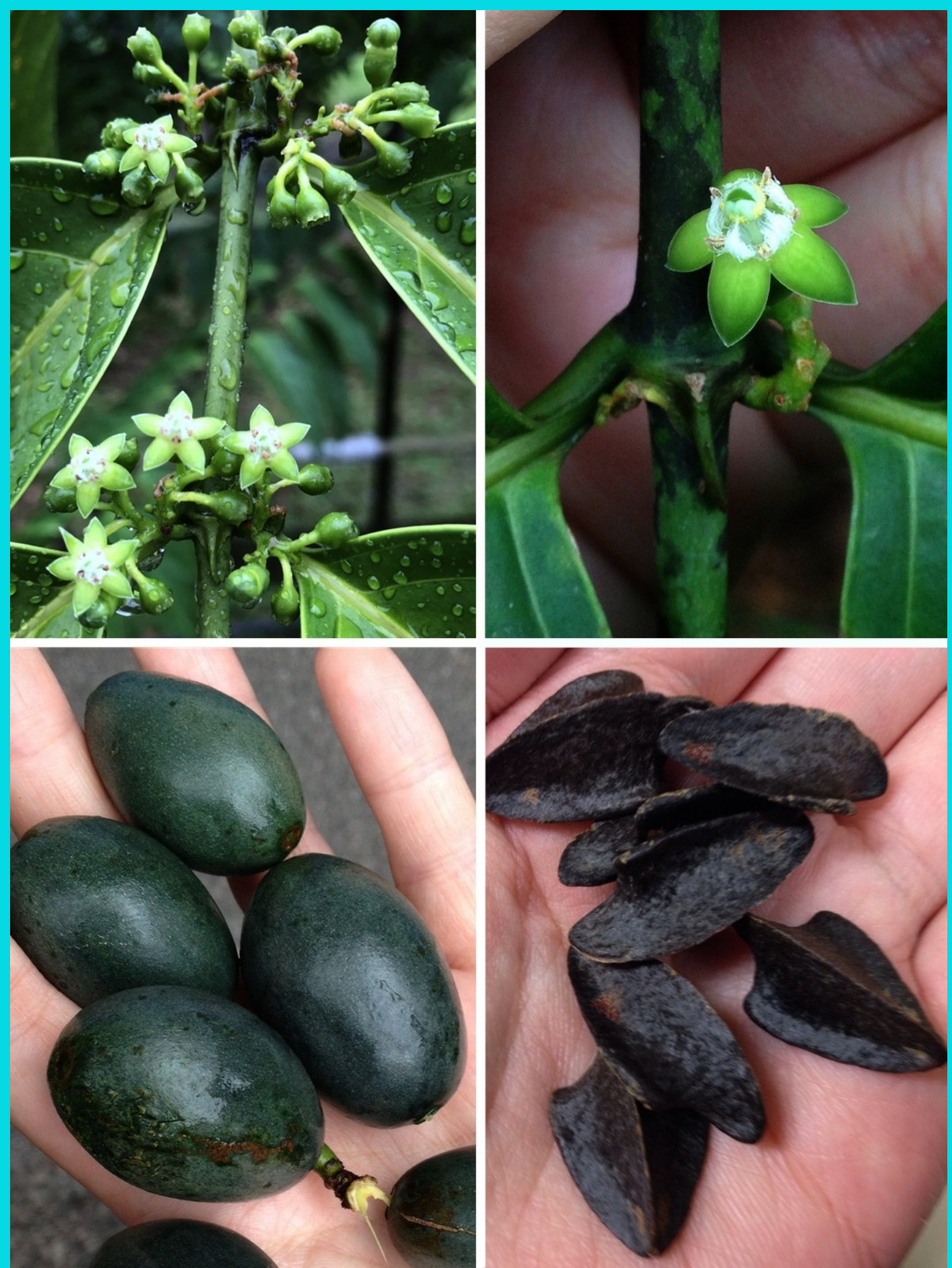

$201817(2)$ 


\section{REINWARDTIA}

\section{A JOURNAL ON TAXONOMIC BOTANY, PLANT SOCIOLOGY AND ECOLOGY}

Vol. 17 (2): 87 - 154, December 18, 2018

\section{Chief Editor}

Kartini Kramadibrata (Mycologist, Herbarium Bogoriense, Indonesia)

\section{Editors}

Dedy Darnaedi (Taxonomist, Herbarium Bogoriense, Indonesia)

Tukirin Partomihardjo (Ecologist, Herbarium Bogoriense, Indonesia)

Joeni Setijo Rahajoe (Ecologist, Herbarium Bogoriense, Indonesia)

Marlina Ardiyani (Taxonomist, Herbarium Bogoriense, Indonesia)

Himmah Rustiami (Taxonomist, Herbarium Bogoriense, Indonesia)

Lulut Dwi Sulistyaningsih (Taxonomist, Herbarium Bogoriense, Indonesia)

Topik Hidayat (Taxonomist, Indonesia University of Education, Indonesia)

Eizi Suzuki (Ecologist, Kagoshima University, Japan)

Jun Wen (Taxonomist, Smithsonian Natural History Museum, USA)

Barry J. Conn (Taxonomist, School of Life and Environmental Sciences, The University of Sydney, Australia)

David G. Frodin (Taxonomist, Royal Botanic Gardens, Kew, United Kingdom)

Graham Eagleton (Wagstaffe, NSW, Australia)

\section{Secretary}

Ruslan Bukhori

\section{Layout}

Liana Astuti

\section{Illustrators}

Subari

Wahyudi Santoso

Anne Kusumawaty

Correspondence on editorial matters and subscriptions for Reinwardtia should be addressed to:

HERBARIUM BOGORIENSE, BOTANY DIVISION,

RESEARCH CENTER FOR BIOLOGY - INDONESIAN INSTITUTE OF SCIENCES

CIBINONG SCIENCE CENTER, JLN. RAYA JAKARTA - BOGOR KM 46,

CIBINONG 16911, P.O. Box 25 CIBINONG

INDONESIA

PHONE (+62) 21 8765066; Fax (+62) 218765062

E-MAIL: reinwardtia@mail.lipi.go.id

http://e-journal.biologi.lipi.go.id/index.php/reinwardtia

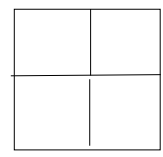

Cover images: Canthiumera robusta K.M.Wong \& X.Y.Ng, spec. nov. Top left: leafy branch with inflorescences; note also keeled stipules. Top right: flower with tufts of pale moniliform hairs visible opposite corolla lobes. Below left: fruits. Below right: pyrenes. Photos: Ang Wee Foong (top left) and X.Y. Ng (remaining images). 
The Editors would like to thank all reviewers of volume 17(2):

Andrew Powling, School of Biological Sciences, University of Portsmouth, Portsmouth, United Kingdom George Argent, Royal Botanic Garden Edinburgh, Edinburgh, United Kingdom

Joan Pereira, Forest Research Centre, Sandakan, Sabah, Malaysia

Jun Yokoyama, Dept. of Biology, Faculty of Science, Yamagata University, Yamagata, Japan

Khoon Meng Wong, Singapore Botanic Gardens, Singapore

Kongkanda Chayamarit, Queen Sirikit Botanic Garden, P.O. Box 7, Mae Rim, Chiang Mai, Thailand 


\title{
AN ASSESSMENT OF PRESENT PLANT DIVERSITY ON THE NATEWA PENINSULA, VANUA LEVU, FIJI
}

Received July 18, 2018; accepted September 27, 2018

\author{
ANDREW POWLING \\ School of Biological Sciences, University of Portsmouth, King Henry I Street, Portsmouth, PO1 2DY, UK. \\ Email: andrew.powling@port.ac.uk; apowling01@btinternet.com
}

\begin{abstract}
POWLING, A. 2018. An assessment of present plant diversity on the Natewa Peninsula, Vanua Levu, Fiji. Reinwardtia 17(2): 125-132. - The Natewa Peninsula, part of the Fijian island of Vanua Levu, is naturally afforested but the forests have been extensively logged in the last 50 years. It is now planned to protect some of the forests from further logging by incorporating them into a National Park. A survey of plant species in the regenerating forests and surrounding land on the Peninsula was performed to assess the taxonomic and ecological diversity of the trees and shrubs, including figs and palms, and also the orchids presently to be found on the Peninsula. The degree of invasion by introduced plant species was also assessed. Of 67 tree and shrub species it was found that 17 were endemic to the Fijian islands, 40 others were indigenous and ten were introduced. The normal habitats of these species included dense, open and secondary forest, showing that trees with a range of ecological characteristics were still present. Endemic and indigenous species of both figs and palms were found, and also terrestrial and epiphytic orchids. No severe infestations of introduced species were observed. It is concluded that the forests of the Peninsula are of sufficient conservation value to justify National Park status.
\end{abstract}

Key words: conservation, trees, Fiji, figs, orchids, palms.

\begin{abstract}
ABSTRAK
POWLING, A. 2018. Penilaian keanekaragaman tumbuhan saat ini di Semenanjung Natewa, Vanua Levu, Fiji. Reinwardtia 17(2): 125-132. - Semenanjung Natewa, bagian dari pulau Vanua Levu di Fiji, secara alami sudah dihutankan namun demikian hutan telah ditebangi secara ekstensif dalam 50 tahun terakhir. Untuk melindungi beberapa hutan dari penebangan lebih lanjut diusulkan untuk memasukkan hutan-hutan tersebut ke dalam Taman Nasional. Sebuah survei jenis tumbuhan di hutan regenerasi dan tanah sekitarnya di semenanjung dilakukan untuk menilai keragaman taksonomi dan ekologi pohon dan semak, termasuk pohon ara dan pohon palem, dan juga anggrek yang saat ini dapat ditemukan di semenanjung. Tingkat invasi oleh jenis tumbuhan pendatang juga dinilai. Dari 67 jenis pohon dan semak ditemukan 17 jenis endemik di kepulauan Fiji, 40 lainnya adalah jenis asli dan sepuluh jenis lainnya adalah jenis pendatang. Habitat normal jenis ini adalah hutan lebat, terbuka dan sekunder, yang menunjukkan bahwa pohon-pohon dengan berbagai karakteristik ekologi masih ada. Jenis endemik dan asli dari buah ara dan palem ditemukan, dan juga anggrek terestrial dan epifit. Tidak ada infestasi berat dari jenis pendatang yang diamati. Disimpulkan bahwa hutan semenanjung mempunyai nilai konservasi yang cukup untuk diusulkan statusnya menjadi Taman Nasional.
\end{abstract}

Kata kunci: Anggrek, buah ara, Fiji, konservasi, palem, pohon.

\section{INTRODUCTION}

The Fijian archipelago in the tropical south-west Pacific consists of about 320 islands, of which the two largest are Viti Levu and Vanua Levu. The Natewa Peninsula makes up the south-easterly part of Vanua Levu. The Peninsula is $60 \mathrm{~km}$ long and is linked at its south-westerly end to the rest of Vanua Levu by an isthmus $2 \mathrm{~km}$ wide (Geological Survey of Fiji, 1965). To the north-west the Peninsula is separated from the bulk of Vanua Levu by Natewa Bay. The villages of Natewa, Vusaratu and Dawa lie on the north-west coast of the Peninsula, overlooking Natewa Bay.

The oldest rocks in Fiji are volcanics of late Eocene age (about 40-35 million years ago) and it is thought that plate tectonic activity has resulted in a series of more or less short-lived volcanic islands being formed in the area since then (Neall \& Trewick, 2008). It is thought that the Fijian flora was able to establish and survive on these volcanic islands (Heads, 2006). Many plant species which are endemic to the Fijian Archipelago have evolved and persist but estimates of the numbers and proportions of endemic species have varied. For instance, Ash (1992) states that 'about 25\%' of the native vascular plant species are endemic whilst Smith (vol. 6, 1996) gives figures of 1318 indigenous flowering plant species of which 812 $(61.6 \%)$ are endemic. These figures differ in part because there are debates about how many species should be recognised and which ones should be defined as indigenous (Heads, 2006).

The landscape of the Natewa Peninsula is rugged, with a maximum altitude of approximately $800 \mathrm{~m}$. The rocks consist of volcanic andesites of 
Miocene and Pliocene age, with epiclastic deposits derived from them (Geological Survey of Fiji, 1965). A large proportion of the forests on the Peninsula were extensively logged from 1969 through to about the year 2000 (T. Raicoi, pers. comm). Some areas were logged two or three times. A condition placed on the logging companies was that no logging should take place within $30 \mathrm{~m}$ of a water course, but it seems that this condition was often not observed. Little effort appears to have been made to re-plant the forests, so natural regeneration has taken place.

Partly as a response to the destruction caused by the logging, there are now plans for the part of the Peninsula in the region of Natewa village to be declared a National Park to save the forest from further logging. However, the question arises of how much the vegetation in the area has suffered as a result of the logging and whether sufficient diversity of the flora remains to justify the creation of a National Park. The survey of the vegetation to be described, although limited in time and geographical scope, attempted to assess the remaining floral diversity.

\section{MATERIALS AND METHODS}

The survey of the flora of the peninsula was performed with the permission and help of the villagers of Natewa, Vusaratu and Dawa, for whom the land is part of their communally owned property, their 'Mataqali'.

The survey was conducted in the months of June and July 2017. The main area in which forest vegetation was surveyed was a tract of land covering approximately $6 \mathrm{~km}^{2}$ and centred on a position with coordinates of $16^{\circ} 37.9^{\prime} \mathrm{S} ; 179^{\circ}$ 45.1' E. All parts of the area were at least $3 \mathrm{~km}$ from the sea. The altitude of the terrain in this area varied from 240 to $420 \mathrm{~m}$, with annual rainfall between 2800 and $3200 \mathrm{~mm}$ (Gale, 1991). Identifications of beach and coastal flora were made near Tuicau Point on the north coast of the Peninsula, $3.5 \mathrm{~km}$ south west of Natewa Village.

Plant specimens (approximately 150 in total) were collected in forests and at forest edges, including beside roads and tracks passing through the forests, and in neighbouring scrub and grasslands. Many specimens were taken whilst measuring trees in forest quadrats in order to calculate tree volumes and carbon content of the forests, the results of which will be reported elsewhere. Plant species were identified using floras by Smith (1979-1996) and Keppel \& Ghazanfar (2011). Photographs were taken of the specimens and some species were later identified or confirmed by comparison of photographs with named specimens in the Herbarium at the Royal Botanic Gardens, Kew, UK.

\section{RESULTS AND DISCUSSION}

The survey concentrated on forest trees and shrubs, which are reported on first, but other plants were also identified. The fig (Ficus), palm and orchid species that were found are dealt with separately, since fig species are very important for the wider ecology of the forest and some endemic palm and orchid species are of great conservation interest. Introduced species are likewise treated separately because of their relevance to the conservation status of the Peninsula.

\section{Forest trees and shrubs}

Table 1 lists 67 tree and shrub species (excluding Ficus species and palms) identified in the survey area, that were found outside cultivation in natural habitats where they appeared not to have been planted. They are arranged in alphabetical order of the 33 families to which they belong. Fifty -seven of the species occur naturally on Fiji, 17 being endemic to the Fijian islands and 40 being indigenous but also occurring elsewhere. Ten species have been introduced to Fiji, all of them existing naturally in the area, outside cultivation. The Table shows the known habitats of the species as listed in Smith (1979-1996), and Keppel \& Ghazanfar (2011). Observations of habitat made during the present study are shown in parentheses.

Most of the forest in the study area was secondary, being in the process of regeneration following the earlier logging. However, some parts were more developed than others so a variety of habitats were present: dense forest on hillsides, ridge tops and river valleys, along with open forest, grasslands and roadsides including old logging roads running through the forest. This allowed species with a variety of habitat requirements to exist in the area. Apparently, many species managed to survive the destruction of the logging. Explanations for this species diversity can be offered: not all species were taken by the loggers, the poor timber species being left (T. Raicoi, pers comm), while small individuals of good timber species would not have been taken either. It is probable that seeds of at least some species would have survived in the soil and other species might have naturally recolonised from outside the area following seed dispersal by birds, bats and wind.

The Natewa Peninsula was presumably the home of much plant diversity before logging took place, since it has high rainfall and diverse topography. There is no list of plant species which grew in the survey area before the logging, so no assessment of plant diversity loss due to logging can be made; but statements about present diversity are now possible. Table 1 shows 41 native species which grow in areas away from the 
Table 1. Trees and shrubs identified on the Natewa Peninsula, arranged alphabetically by Family.

\begin{tabular}{|c|c|c|c|}
\hline Species & Family & Forest type & Status \\
\hline Dracontomelon vitiense Engl. & Anacardiaceae & Coastal & Indigenous \\
\hline Rhus simarubifolia A.Gray & Anacardiaceae & Open & Indigenous \\
\hline Cananga odorata (Lam.) Hook. f. \& Thoms. & Annonaceae & Coastal & Introduced \\
\hline Alstonia costata (G.Forst.) R.Br. & Apocynaceae & Secondary & Indigenous \\
\hline Alstonia macrophylla Wall. ex G.Don & Apocynaceae & (Secondary) & Introduced \\
\hline Alstonia vitiensis Seem. & Apocynaceae & Open, Dense & Endemic \\
\hline Cerbera manghas $\mathrm{L}$ & Apocynaceae & Open, Dense & Indigenous \\
\hline Agathis macrophylla (Lindl.) Mast. & Araucariaceae & Secondary, Dense & Indigenous \\
\hline Spathodea campanulata Beauv. & Bignoniaceae & Secondary, Open, Dense & Introduced \\
\hline Cordia subcordata Lam. & Boraginaceae & Coastal & Indigenous \\
\hline Casuarina equisetifolia J.R. \& G.Forst. & Casuarinaceae & Coastal & Indigenous \\
\hline Gymnostoma vitiense L.A.S.Johnson & Casuarinaceae & Open, Dense & Endemic \\
\hline Atuna racemosa Raf. & Chrysobalanaceae & Open, Dense & Indigenous \\
\hline Parinari insularum A.Gray & Chrysobalanaceae & Open, Dense & Indigenous \\
\hline Terminalia litoralis Seem. & Combretaceae & Coastal & Indigenous \\
\hline Geissois ternata A.Gray & Cunoniaceae & Open, Dense & Indigenous \\
\hline Cyathea lunulata (G.Forst.) Copel. & Cyatheaceae & (Open, Dense) & Indigenous \\
\hline Endospermum robbieanum A.C.Sm. & Euphorbiaceae & Open & Endemic \\
\hline Macaranga harveyana (Müll.Arg.) Müll.Arg. & Euphorbiaceae & Secondary, Open, Dense & Indigenous \\
\hline Macaranga magna Turrill & Euphorbiaceae & Open, Dense & Indigenous \\
\hline Macaranga seemannii (Müll.Arg.) Müll.Arg. & Euphorbiaceae & Open, Dense & Indigenous \\
\hline Fagraea gracilipes A.Gray & Gentianaceae & Open, Dense & Endemic \\
\hline Scaevola sericea Vahl & Goodeniaceae & Coastal & Indigenous \\
\hline Calophyllum cerasiferum Vesque & Guttiferae & Secondary, Dense & Endemic \\
\hline Calophyllum inophyllum L. & Guttiferae & Coastal & Indigenous \\
\hline Calophyllum vitiense Turrill & Guttiferae & Open, Dense & Endemic \\
\hline Hernandia nymphiifolia (J.Presl) Kubitzki & Hernandiaceae & Coastal & Indigenous \\
\hline Gmelina vitiensis (Seem.) A.C.Sm. & Labiatae & Dense & Endemic \\
\hline Cinnamomum verum J.Presl & Lauraceae & (Dense) & Introduced \\
\hline Barringtonia asiatica (L.) Kurz & Lecythidaceae & Coastal & Indigenous \\
\hline Barringtonia edulis Seem. & Lecythidaceae & Open, Dense & Indigenous \\
\hline Inocarpus fagifer (Parkinson) Fosberg & Leguminosae & Coastal & Indigenous \\
\hline Intsia bijuga (Colebr.) Kuntze & Leguminosae & Coastal & Indigenous \\
\hline Maniltoa grandiflora (A.Gray) Scheffer & Leguminosae & Open, Dense & Indigenous \\
\hline
\end{tabular}


Table 1. (continued)

\begin{tabular}{|c|c|c|c|}
\hline Species & Family & Forest type & Status \\
\hline Millettia pinnata (L.) Panigrahi & Leguminosae & Coastal & Indigenous \\
\hline Serianthes melanesica Fosberg & Leguminosae & Dense & Endemic \\
\hline $\begin{array}{l}\text { Grewia crenata (J.R. \& G.Forst.) Schinz \& Guil- } \\
\text { laumin }\end{array}$ & Malvaceae & Secondary, Open, Dense & Indigenous \\
\hline Hibiscus tiliaceus L. & Malvaceae & Coastal & Indigenous \\
\hline Kleinhovia hospita L. & Malvaceae & Coastal & Indigenous \\
\hline Thespesia populnea (L.) Solander ex Correa & Malvaceae & Coastal & Indigenous \\
\hline Dysoxylum lenticellare Gillespie & Meliaceae & Secondary, Open, Dense & Endemic \\
\hline Swietenia macrophylla King & Meliaceae & (Secondary, Open) & Introduced \\
\hline Swietenia mahogani (L.) Jacq. & Meliaceae & (Secondary, Open) & Introduced \\
\hline Myristica grandifolia A.DC. & Myristicaceae & Secondary, Dense & Endemic \\
\hline Decaspermum vitiense (A.Gray) Niedenzu & Myrtaceae & Open & Endemic \\
\hline Metrosideros collina A.C.Sm. var. collina & Myrtaceae & Dense & Indigenous \\
\hline Syzygium malaccense (L.) Merr. \& Perry & Myrtaceae & Open, Dense & Introduced \\
\hline Syzygium neurocalyx (A.Gray) Christophersen & Myrtaceae & Dense & Indigenous \\
\hline Syzygium wolfii (Gillespie) Merr. \& Perry & Myrtaceae & Secondary, Open, Dense & Endemic \\
\hline Bischofia javanica Blume & Phyllanthaceae & Open, Dense & Indigenous \\
\hline Glochidion cf. amentuligerum (Müll. Arg.) Croizat & Phyllanthaceae & Open, Dense & Endemic \\
\hline Glochidion seemannii Müll. Arg. & Phyllanthaceae & Secondary, Open, Dense & Endemic \\
\hline Pinus caribaea Morelet & Pinaceae & (Secondary) & Introduced \\
\hline Piper aduncum L. & Piperaceae & Secondary & Introduced \\
\hline Dacrydium nidulum de Laubenfels & Podocarpaceae & Open, Dense & Indigenous \\
\hline Podocarpus neriifolius D.Don & Podocarpaceae & Open, Dense & Indigenous \\
\hline Retrophyllum vitiense (Seem.) C.N.Page & Podocarpaceae & Dense & Indigenous \\
\hline Columbrina asiatica (L.) Brongn. & Rhamnaceae & Coastal & Indigenous \\
\hline Guettarda speciosa $\mathrm{L}$. & Rubiaceae & Coastal & Indigenous \\
\hline Morinda citrifolia $\mathrm{L}$. & Rubiaceae & Coastal & Introduced \\
\hline Mussaenda raiateensis J.W.Moore & Rubiaceae & Secondary, Open, Dense & Indigenous \\
\hline Neonauclea forsteri (Seem. ex Havil.) Merr. & Rubiaceae & Open, Dense & Indigenous \\
\hline Pometia pinnata J.R. \& G.Forst. & Sapindaceae & Open & Indigenous \\
\hline Burckella fijiensis (Hemsl.) A.C.Sm. \& S.Darwin & Sapotaceae & Open, Dense & Endemic \\
\hline Palaquium hornei (Hartog ex Baker) Dubard & Sapotaceae & Dense & Endemic \\
\hline Palaquium porphryeum A.C.Sm. \& S.Darwin & Sapotaceae & Dense & Endemic \\
\hline Dendrocnide harveyi (Seem.) Chew & Urticaceae & Dense & Indigenous \\
\hline
\end{tabular}

Note: Information on Family, Forest type and Status taken from Smith (1979-1996), Keppel \& Ghazanfar (2011) and Mabberley (2008). Forest types in parentheses are the result of observations made during the present study. 
Table 2. Species of genus Ficus (Moraceae) found on the Natewa Peninsula.

\begin{tabular}{llll}
\hline Species & Subgenus & Section & Status \\
\hline Ficus benjamina L. & Urostigma & Conosycea & Introduced \\
Ficus elastica Roxb. ex Hornem. & Urostigma & Conosycea & Introduced \\
Ficus fulvo-pilosa Summerhayes & Sycidium & Sycidium & Endemic \\
Ficus greenwoodii Summerhayes & Sycidium & Sycidium & Endemic \\
Ficus masonii Horne ex Baker & Sycidium & Sycidium & Endemic \\
Ficus obliqua G.Forst. & Urostigma & Malvanthera & Indigenous \\
Ficus smithii Horne ex Baker & Pharmacosycea & Oreosycea & Indigenous \\
var. robusta Corner & & & \\
Ficus vitiensis Seem. & Sycomorus & Adenosperma & Endemic \\
\hline
\end{tabular}

Note: Information on subgenus and section taken from van Noort \& Rasplus (2018). Information on status from Smith (1979-1996).

coast, of which 17 (41.5\%) are endemic to Fiji. Of the 100 rainforest tree species described by Keppel \& Ghazanfar (2011), 38 were found in the survey (a total that includes two Ficus species listed in Table 2). A further 24 indigenous and endemic species not fully described by Keppel \& Ghazanfar (2011) were also found. These figures show that the area proposed for the National Park still hosts a considerable diversity of woody plants, including many endemic species that should be conserved.

Table 1 includes 18 species, listed with the forest type 'Coastal', which grew in forest immediately behind the beach at Tuicau Point, within the proposed National Park. Most of these species belong to the coastal strand-line vegetation, specifically the Barringtonia formation (Whitten et al., 2002). This vegetation consists of species which are common on coastlines throughout the Indo-Pacific region, due to their ability to disperse from island to island by fruits and seeds that can float and survive in seawater. As a result, none of these species is endemic to Fiji.

\section{Fig (Ficus) species}

In total eight species of Ficus (figs), family Moraceae, were found in forests, roadsides and riversides (Table 2). Two species are introduced ( $F$. benjamina and $F$. elastica), whilst the other six are native (Smith, 1979-1996). It is quite possible that other Ficus species exist on the Peninsula but were not found during the survey. The Table also shows the subgenera and sections to which the species belong (van Noort \& Rasplus, 2018).

Ficus proved to be the most species-rich genus of native plants found on the Natewa Peninsula. Harrison (2005) has previously observed that Ficus is usually among the most species-rich genera in tropical lowland forests. He suggested it is because fig species have been able to diversify into a wide range of ecological niches. They have effective long-distance seed dispersal due to birds and bats eating the 'fruits' (syconia), then excreting the intact seeds. Fig plants also have a very specific pollination system involving species of fig wasps which are specific to particular fig species and can transfer pollen long distances from fig to fig (Cook \& Rasplus, 2003). The result is that fig species have been able to colonise new habitats, then evolve and form new species adapted to small and rare niches, but are still able to cross-pollinate despite individuals being few and far between (Harrison, 2005).

Another consequence of the Ficus pollination system involving fig wasps is that within a forest the individual fig plants making up a population must produce ripe syconia asynchronously, so that at all times there are figs ready to receive fig wasps. This allows the fig wasps to complete their life cycle and maintain their local population. As a result, ripe figs are always present in the forest and supply food for animal species. Indeed, Ficus species have been described as 'keystone' species in tropical forests (Kinniard et al., 1999), since they provide a reliable, year-round, food supply to many forest animals. Birds and fruit bats are among the species particularly reliant on them (Ryan, 2000). A requirement for the maintenance of fig species in a forest is that the conserved area should be large enough to hold viable populations of the species and their pollinating fig wasps. This should be considered when setting the boundaries of a future National Park.

Ficus species are used as 'framework' species in efforts to regenerate tropical rainforests, since some of them can be planted in open situations and will then attract foraging birds and fruit bats to the area (Elliott et al., 2013). The incoming frugivores will bring seeds of other tree species in 
Table 3. Species of palm (Palmae) found on the Natewa Peninsula.

\begin{tabular}{lll}
\hline Species & Habitat & Status \\
\hline Areca catechu L. & Cultivation & Introduced \\
Balaka macrocarpa Burret & Forest & Endemic to Vanua Levu \\
Balaka seemannii (H.Wendl.) Becc. & Forest & Endemic to Vanua Levu \& Taveuni \\
Cocos nucifera L. & Cultivation, coastal & Introduced, naturalising \\
Elaeis guineensis Jacq. & Cultivation, forest & Introduced, naturalising \\
Pritchardia pacifica Seem. \& H.Wendl. & Cultivation & Introduced \\
Veitchia filifera (H.Wendl.) H.E.Moore & Forest & Endemic to Vanua Levu \& Taveuni \\
Veitchia joannis H.Wendl. & Forest (coastal) & Endemic to Fijian Islands \\
\hline
\end{tabular}

Note: Information on habitat from the present study. Information on status from Smith (1979-1996), Watling (2005) and Hodel (2010).

their guts and deposit them at the site of the regenerating forest. The presence of naturally occurring Ficus species in the Natewa Peninsula must aid the regeneration of the forest after logging.

An interesting aspect of Table 2 is that it shows the presence of three Ficus species in the subgenus Sycidium, section Sycidium: $F$. fulvo-pilosa, F. greenwoodii and $F$. masonii. Four other Ficus species in the same subgenus and section are known in Fiji: F. bambusifolia Seem., F. barclayana (Miq.) Summerhayes, F. scabra G.Forst. and F. storckii Seem. (Smith, 1979-1996). All except two of these seven species are endemic to Fiji; the two exceptions being $F$. scabra and $F$. storckii which also occur on other islands in the south west Pacific. Therefore, it appears that there has been an adaptive radiation on Fiji of Ficus species in subgenus Sycidium, section Sycidium. Such a radiation would imply a corresponding radiation of pollinating fig wasp species (Cook \& Rasplus, 2003).

\section{Palms (Palmae)}

Four endemic species of palms were found during the survey (Table 3). Of these, Balaka seemannii is only known from Vanua Levu and the neighbouring island of Taveuni but is widespread on these islands (Hodel, 2010). The other species of Balaka, B. macrocarpa, is only known from three sites on Vanua Levu, which include the Natewa Peninsula (Hodel, 2010). It is classified as Endangered by the IUCN (2017). The species was found to be common in secondary forests in the survey area, with many individuals bearing developing fruit, but the general rarity of the species is one of the prime reasons for conserving vegetation on the Natewa Peninsula. A further species, Veitchia filifera, was found in, and on the edges of, forest and is one of the commonest forest tree species. It is endemic to Vanua Levu and Taveuni (Watling, 2005). Its congeneric relative, $V$. joannis, was found in forest near the coast but not in the main survey area.

Other palm species were found in cultivation or were escaping from cultivation (Table 3 ). Notable in this regard was Elaeis guineensis, the oil palm. Some large specimens were found on open ground near a road; they were the remnants of a failed trial to see if the species could be grown commercially (T. Raicoi, pers. comm.). Interestingly, young individuals were found in the nearby secondary forest, so maybe the species will become naturalised in the area.

\section{Orchids (Orchidaceae)}

A list of orchid species found is presented in Table 4. These species were identified from photographs by Andre Schuiteman of the Royal Botanic Gardens, Kew. By far the most common species was Spathoglottis pacifica, a terrestrial orchid able to grow in high light intensities and in apparently poor and nutrient deficient soils. It was found in forest clearings but more often at roadsides and other open places with disturbed and bare ground. A terrestrial orchid which was only found in forests in low light intensities was Calanthe hololeuca, which flowered in the month of June. A further terrestrial orchid of the forest was Peristylus maculifer. Five species of epiphytic orchid were found. One species, Liparis elegans, grew in closed and dark forest; the remaining four species were capable of growth on trees in more open situations.

The existence of terrestrial and epiphytic orchids in the forest is encouraging. It suggests that destruction of the forest by loggers was not 
Table 4. Species of orchid (Orchidaceae) found on the Natewa Peninsula.

\begin{tabular}{lll}
\hline Species & Habitat & Status \\
\hline Calanthe hololeuca Rchb. f. & Terrestrial & Indigenous \\
Dendrobium cf. spathulatum L.O.Williams & Epiphytic & Endemic \\
Dendrobium cf. tokai Rchb. f. & Epiphytic & Indigenous \\
Dendrobium catillare Rchb. f. & Epiphytic & Indigenous \\
Liparis elegans Lindl. & Epiphytic & Indigenous \\
Oberonia heliophila Rchb. f. & Epiphytic & Indigenous \\
Peristylus maculifer (C.Schweinf.) Renz \& Vodonaivalu & Terrestrial & Indigenous \\
Spathoglottis pacifica Rchb. f. & Terrestrial & Indigenous \\
\hline
\end{tabular}

Note: Information on habitat and status from Smith (1979-1996). Note that D. catillare is called D. purpureum in the Flora Vitiensis Nova (Smith, 1979-1996), while what is called D. catillare there is another species, D. taveuniense (A. Schuiteman, pers. comm).

complete since the various species of orchid have either survived the logging or have found the regenerating forest suitable for their reestablishment.

\section{Introduced species}

The list of trees and shrubs (Table 1) includes ten introduced species. Of these, only two, Spathodea campanulata and Syzygium malaccense, appear to be extensively naturalised in the forest. Fortunately, the former species does not occur as frequently on the Natewa Peninsula as it does in northern Vanua Levu. The other eight species persist mostly at roadsides and on forest edges. Swietenia macrophylla has been established in plantations in some places and it remains to be seen how far it can spread naturally. Unfortunately, the tannin-rich leaves and the ground water that runs from $S$. macrophylla plantations suppress the growth of other trees, so these plantations hinder the natural regeneration of surrounding forests (T. Raicoi, pers. comm; Cernansky, 2018).

Disturbed forest and forest edges are often extensively overgrown by the indigenous scrambler Merremia peltata (L.) Merr. (Convolvulaceae), which must retard successional processes in many places. A species that can dominate in open situations in the tropics is the scrambler Mikania micrantha Kunth (Compositae); this has been introduced to Fiji and is often a problem due to its rampant growth, but on the Natewa Peninsula it appears to be only a minor part of the vegetation in disturbed places. Another introduced species which is a problem elsewhere due to rapid growth and bird dispersal is Lantana camara L. (Verbenaceae). This is present on the Natewa Peninsula but does not appear to be common, growing on waste ground near human habitation.
Two non-native species found near forest edges and showing some penetration into disturbed forest are Piper aduncum L. (Piperaceae) and Clidemia hirta (L.) D.Don (Melastomataceae). Indigenous species usually dominate in forest clearings, with the fern Dicranopteris linearis (Burm. f.) Underw. (Gleicheniaceae) and the clubmoss Lycopodium cernuum L. (Lycopodiaceae) often being prominent ground-layer plants.

Three grass species (Graminae) are very common beside roads and tracks. Two of these are native: Imperata conferta (J.Presl) Ohwi and Miscanthus floridulus (Labill.) Warb., but the other is the introduced Arundo donax L. The Arundo has been widely planted to stabilise road verges and now is common and spreading along roadsides.

\section{CONCLUSIONS}

The forested area studied has been severely disturbed by logging in the recent past but is now regenerating. Table 1 shows that species of secondary forests occur in the area but that many species of mature forest, both open and dense, are present as well. The species show taxonomic diversity as well as habitat diversity, and many endemic species, which have high conservation value, grow in the regenerating forest. At least six native Ficus species are present and the figs they produce attract birds and fruit bats which bring with them the seeds of other forest trees. The forest still contains rare endemic palm species, together with terrestrial and epiphytic orchids, further adding to its conservation value. These observations suggest that the forest is, at present, worth conserving and should increase in conservation value if it is protected from further logging by incorporation into a National Park. 


\section{ACKNOWLEDGEMENTS}

I am indebted to the villagers of Natewa, Vusaratu and Dawa for their hospitality and particularly to Tevita Raicoi of Dawa village for guidance in the forest and for local information. I am also indebted to Andre Schuiteman of the Royal Botanic Gardens, Kew, for identifying the orchid species. The survey described was part of a programme of research in Fiji organised by Operation Wallacea and I thank Tim Coles for the invitation to take part. Thanks also to David Blakesley and Eric Clement for reading and commenting on a draft of this paper; and to an anonymous reviewer for constructive comments. Eric Clement helpfully lent his copy of Smith's Flora.

\section{REFERENCES}

ASH, J. 1992. Vegetation ecology of Fiji: past, present and future perspectives. Pacific Science 46: 111-127.

CERNANSKY, R. 2018. How to rebuild a forest. Nature 560: 542-544.

COOK, J. M. \& RASPLUS, J. Y. 2003. Mutualists with attitude: coevolving fig wasps and figs. Trends in Ecology and Evolution 18: 241-248.

ELLIOTT, S. D., BLAKESLEY, D. \& HARDWICK, K. 2013. Restoring tropical rainforests: a practical guide. Royal Botanic Gardens, Kew.

GALE, I. N. 1991. Hydrogeological Maps of Viti Levu and Vanua Levu. Mineral Resources Department, Suva. Maps reproduced in Watling, 2005.

GEOLOGICAL SURVEY OF FIJI. 1965. Geological Map of Fiji, Suva, Fiji.
HARRISON, R. D. 2005. Figs and the diversity of tropical rainforests. BioScience 55: 1053-1064.

HEADS, M. 2006. Seed plants of Fiji: an ecological analysis. Biol. J. Linn. Soc. 89: 407431.

HODEL, D. R. 2010. A synopsis of the genus Balaka. Palms 54: 161-188.

IUCN (International Union for Conservation of Nature) 2017. URL: http://www.iucnredlist.org/ details/summary/38434/0 (Accessed on 24/09/18).

KEPPEL, G. \& GHAZANFAR, S. A. 2011. Trees of Fiji: A Guide to 100 Rainforest Trees. $3^{\text {rd }}$ ed. Secretariat to the Pacific Community \& Deutsche Gesellschaft für Internationale Zusammenarbeit, Suva, Fiji.

KINNIARD, M. F., O'BRIEN, T. G. \& SURYADI, S. 1999. The importance of figs to Sulawesi's imperilled wildlife. Tropical Biodiversity 6: 5-18.

MABBERLEY, D. J. 2008. Mabberley's PlantBook. $3^{\text {rd }}$ ed. Cambridge University Press, Cambridge. UK.

NEALL, V. E. \& TREWICK, S. A. 2008. The age and origin of the Pacific islands: a geological overview. Phil. Trans. R. Soc. B. 363: 32933308.

RYAN, P. 2000. Fiji's Natural Heritage. $2^{\text {nd }}$ ed. Exisle Publishing, Auckland.

SMITH, A. C. 1979-1996. Flora Vitiensis Nova. A New Flora of Fiji (Spermatophytes only). Volumes 1-6. National Tropical Botanic Garden, Lawai, Kauai, Hawaii.

VAN NOORT, S. \& RASPLUS, J. Y. 2018. Figweb: figs and fig wasps of the world. URL: www.figweb.org (Accessed on 04/07/18).

WATLING, D. 2005. Palms of the Fiji Islands. Environmental Consultants, Suva, Fiji.

WHITTEN, T., MUSTAFA, M. \& HENDERSON, G. S. 2002. The Ecology of Sulawesi. Periplus Editions (HK) Ltd., Hong Kong. 


\section{INSTRUCTION TO AUTHORS}

Scope. Reinwardtia is a scientific regular journal on plant taxonomy, plant ecology and ethnobotany published in June and December. Manuscript intended for a publication should be written in English.

Titles. Titles should be brief, informative and followed by author's name and mailing address in oneparagraphed.

Abstract. English abstract followed by Indonesian abstract of not more than 250 words. Keywords should be given below each abstract.

Manuscript. Manuscript is or iginal paper and represent an article which has not been published in any other journal or proceedings. The manuscript of no more than 36 pages by using Times New Roman 11, MS Word for Windows of A4 with double spacing, submitted to the editor through Reinwardtia online journal system and < reinwardtia@mail.lipi.go.id>. New paragraph should be indented in by 5 characters. For the style of presentation, authors should follow the latest issue of Reinwardtia very closely. Author(s) should send the preferred running title of the article submitted. Every manuscript will be sent to two blind reviewers.

Identification key. Taxonomic identification key should be prepared using the aligned couplet type.

Nomenclature. Strict adherence to the International Code of Nomenclature is observed, so that taxonomic and nomenclatural novelties should be clearly shown. English description for new taxon proposed should be provided and the herbaria where the type specimens area deposited should be presented. Name of taxon in taxonomic treatment should be presented in the long form that is name of taxon, author's name, year of publication, abbreviated journal or book title, volume, number and page.

Map/line drawing illustration/photograph. Map, line drawing illustration, or photograph preferably should be prepared in landscape presentation to occupy two columns. Illustration must be submitted as original art accompanying, but separated from the manuscript. The illustration should be saved in JPG or GIF format at least 350 pixels. Legends or illustration must be submitted separately at the end of the manuscript.

References. Bibliography, list of literature cited or references follow the Harvard system as the following examples.

Journal : KRAENZLIN, F. 1913. Cyrtandraceae novae Philippinenses I. Philipp. J. Sci. 8: 163-179.

MAYER, V., MOLLER, M., PERRET, M. \& WEBER, A. 2003. Phylogenetic position and generic differentiation of Epithemateae (Gesneriaceae) inferred from plastid DNA sequence data. American J. Bot. 90: 321-329.

Proceedings : TEMU, S. T. 1995. Peranan tumbuhan dan ternak dalam upacara adat "Djoka Dju" pada suku Lio, Ende, Flores, Nusa Tenggara Timur. In: NASUTION, E. (Ed.). Prosiding Seminar dan Lokakarya Nasional Etnobotani II. LIPI \& Perpustakaan Nasional: 263-268. (In Indonesian).

SIMBOLON, H. \& MIRMANTO, E. 2000. Checklist of plant species in the peat swamp forests of Central Kalimantan, Indonesia. In: IWAKUMA, T., INOUE, T., KOHYAMA, T., OSAKI, M., SIMBOLON, H., TACHIBANA, H., TAKAHASHI, H., TANAKA, N., YABE, K. (Eds.). Proceedings of the International Symposium on: Tropical Peatlands. Pp.179 - 190.

Book : RIDLEY, H. N. 1923. Flora of the Malay Peninsula 2. L. Reeve \& Co. Ltd, London.

Part of Book : BENTHAM, G. 1876. Gesneriaceae. In: BENTHAM, G. \& HOOKER, J. D. Genera Plantarum 2. Lovell Reeve \& Co., London. Pp. 990-1025.

Thesis : BAIRD, L. 2002. A Grammar of Kéo: An Austronesian Language of East Nusantara. Australian National University, Canberra. [PhD. Thesis].

Website : http://www.nationaalherbarium.nl/fmcollectors/k/KostermansAJGH.html. (Accessed 15 February 2012). 


\section{Reinwardtia}

Published by Herbarium Bogoriense, Botany Division, Research Center for Biology, Indonesian Institute of Sciences

Address: Jln. Raya Jakarta-Bogor Km. 46 Cibinong 16911, P.O. Box 25 Cibinong

Telp. (+62) 21 8765066; Fax (+62) 218765062

LIPI

Email: reinwardtia@mail.lipi.go.id

\section{REINWARDTIA Author Agreement Form}

Title of article

Name of Author(s) :

I/We hereby declare that:

- $\mathrm{My} / \mathrm{Our}$ manuscript was based on my/our original work.

- It was not published or submitted to other journal for publication.

- I/we agree to publish my/our manuscript and the copyright of this article is owned by Reinwardtia.

- We have obtained written permission from copyright owners for any excerpts from copyrighted works that are included and have credited the sources in our article. 



\section{REINWARDTIA}

Vol. 17. No. 2. 2018

CONTENTS

LAODE ALHAMD. Ecological study of the arrowroot (Tacca leontopetaloides (L.) Kuntze) at Karimunjawa National Park (KNP), Central Java

YASPER MICHAEL MAMBRASAR \& PRIMA W. K. HUTABARAT. Rhododendron meagaii, a new species of Rhododendron subgenus Vireya (Ericaceae) from Papua, Indonesia

K. M. WONG, RIDHA MAHYUNI, XIN YI NG \& LOUISE NEO. Flora of Singapore Precursors, 8. Systematy of the new Southeast Asian genera Canthiumera and Dibridsonia (Rubiaceae: Vanguerieae), with notes on plant architecture and reproductive ecology

ANDREW POWLING. An assessment of present plant diversity on the Natewa Peninsula, Vanua Levu, Fiji 125

ASEP SADILI, KUSWATA KARTAWINATA, HERWASONO SOEDJITO \& EDY NASRIADI SAMBAS. Tree species diversity in a pristine montane forest previously untouched by human activities in Foja Mountains, Papua, Indonesia

Reinwardtia is a LIPI accredited Journal (792/AU3/P2MI-LIPI/04/2016)

http://e-journal.biologi.lipi.go.id/index.php/reinwardtia

Herbarium Bogoriense

Botany Division

Research Center for Biology - Indonesian Institute of Sciences

Cibinong Science Center

Jln. Raya Jakarta - Bogor, Km 46

Cibinong 16911, P.O. Box 25 Cibinong

Indonesia 